\title{
The effect of potentially toxic cyanobacteria on ciliates (Ciliophora)
}

\author{
Joanna Kosiba • Elżbieta Wilk-Woźniak • Wojciech Krztoń
}

Received: 15 June 2018/Revised: 27 July 2018/Accepted: 24 September 2018/Published online: 10 October 2018

(C) The Author(s) 2018

\begin{abstract}
The most frequently observed cyanotoxins are microcystins. They trigger a cascade of events leading to cellular responses. The hypothesis of the study was that cyanobacteria affect ciliates as solitary species and as assemblages. The aim of our study was to determine whether ciliates respond to cyanobacteria because of the presence of cyanotoxins (microcystins-MC). We set up experiments with toxic (Planktothrix agardhii and Microcystis aeruginosa) and non-toxic (Aphanizomenon flos-aquae) cyanobacteria, solitary Spirostomum sp. (Ciliophora), and a simple ciliate assemblage. Predicted values showed statistically significant increase during the solitary Spirostomum sp. abundance in the presence of toxic $P$. agardhii (MC total concentration in cells $323.9 \mu \mathrm{g} / \mathrm{l}$ ) and $M$. aeruginosa (MC total concentration in cells $31.9 \mu \mathrm{g} / \mathrm{l})$ but a decrease in the presence of non-toxic A. flos-aquae. The abundance of Spirostomum sp., being a component of ciliate assemblage, decreased
\end{abstract}

Handling editor: Judit Padisák

Electronic supplementary material The online version of this article (https://doi.org/10.1007/s10750-018-3783-9) contains supplementary material, which is available to authorized users.

J. Kosiba $(\bowtie) \cdot$ E. Wilk-Woźniak · W. Krztoń Institute of Nature Conservation, Polish Academy of Sciences, al. Adama Mickiewicza 33, 31-120 Kraków, Poland

e-mail: kosiba@iop.krakow.pl significantly in the presence of all the three species of cyanobacteria due to competition from small-sized ciliate species that graze bacteria more effectively compared to large-cell-sized Spirostomum. We conclude that toxic cyanobacteria may affect ciliates in various ways, not necessarily because of production of toxins. As a consequence of the presence cyanotoxins, a cascading effect of passing carbon in the food web might be induced.

Keywords Microcystins - Spirostomum sp. · Cyanotoxins · Ciliophora

\section{Introduction}

Cyanobacteria are prokaryotic, autotrophic organisms which, developing in mass, create water blooms. One potentially hazardous consequence of cyanobacterial blooms is the production of toxins (e.g. Carmichael, 1994). Various types of cyanotoxins are produced by different species of cyanobacteria, e.g. species from genera: (a) Anabaena, Aphanizomenon and Oscillatoria produce anatoxin-a; (b) Aphanizomenon, Planktothrix, Anabaena, Cylindrospermopsis and Lyngbya produce saxitoxins; (c) Microcystis, Planktothrix, Dolichospermum and Aphanizomenon produce microcystins; (d) Nodularia produces nodularins; and (e) Cylindrospermopsis and Aphanizomenon produce 
cylindrospermopsins (Codd et al., 1995, 2005; Sivonen \& Jones, 1999; Buratti et al., 2017).

Among toxins, hepatotoxins, and especially microcystins (MCs), which are heptapeptides (Carmichael, 1992), are the most frequently observed and have been well studied (Zurawell et al., 2005; Mantzouki et al., 2018). They are endotoxins (Rapala et al., 1997) and are not released into water until cell lysis (Rohrlack \& Hyenstrand, 2007).

Microcystins induce abnormal signalling in multiple pathways mediated by protein phosphatase 2 (PP2A), resulting in increased protein phosphorylation that triggers a cascade of events leading to a series of cellular responses such as: modification of the cytoskeleton and disruption of actin filaments, oxidative stress, induction of apoptosis, and reduced DNA repair or cell proliferation leading to tumour promotion (Codd et al., 1995).

Primary consumers of cyanobacteria (such as protists, rotifers, copepods and cladocerans) can be directly contaminated by consuming cyanobacterial cells (Ferrão-Filho \& Koslowsky-Suzuki, 2011). Next, predators on protists and animals can be indirectly contaminated and spread the MCs to other organisms via trophic transfer (Ibelings et al., 2005; Gołdyn et al., 2010; Koslowsky-Suzuki et al., 2012). However, cyanotoxins may be passed into the food web not only because they are cumulated in the invertebrates that consume cyanobacteria cells but also because toxins might be bound to the outside part of cells of protists and animals. This way, cyanotoxins may also be transferred via planktonic animals to higher levels of the food chain.

Although a great deal of research has shown the negative effect of toxic cyanobacteria on metazooplankton (Lampert, 1987; Wilson et al., 2006), much less has been focused on protists (Maršálek \& Bláha, 2004; Combes et al., 2013; Tirjaková et al., 2016).

Protists are an important component of the water trophic network, particularly in lakes where cyanobacterial filaments or colonies are too large to be eaten by zooplankton (Havens, 1998). However, more recently, their role has been much appreciated as a very important link in the microbial loop (Sommer et al., 2012). A prominent group of protists constitutes ciliates that are a key component in energy transfer from microbial elements to the higher trophic levels in the food chain (Sherr \& Sherr, 1994).
An understanding of the functionality of different group of species and changes in the food web network of water ecosystems is important because a reduction or alteration of the planktonic population can cause a deficit or an unbalance in food availability for higher levels of the trophic web (Zaccaroni \& Scaravelli, 2008). Based on the assumption that a decrease in the number of ciliates in water bodies containing toxic cyanobacteria is a result of cyanobacteria producing toxic compounds that induce harmful effects to these organisms (Martins et al., 2011), we hypothesised that cyanobacteria affect ciliates as solitary species and as assemblages. Our previous field studies showed that cyanobacterial blooms significantly lowered diversity, density and biomass of ciliate communities (Kosiba et al., 2018). The aim of our study was to determine whether ciliates respond to cyanobacteria because of the presence of cyanotoxins (microcystins).

\section{Materials and methods}

To determine whether potentially toxic cyanobacteria affect ciliates, we set up four experiments (Fig. 1). For the experiments, we used the biomass of species as follows: (1) three species of potentially toxic cyanobacteria (Aphanizomenon flos-aquae Ralfs ex Bornet \& Flahault, Microcystis aeruginosa Kütz. and Planktothrix agardhii (Gomont) Anagnostidis \& Komárek); (2) solitary species of ciliates (Spirostomum sp.); and (3) a simple ciliate assemblage consisting of four species (Spirostomum sp., Euplotes patella (Müller), Strobilidium sp. and Paramecium aurelia-complex). Among the ciliates, we chose Spirostomum sp. because the species from this genus were found to be sensitive to cyanotoxins (Tarczyńska et al., 2001). Cyanobacteria biomasses used for experiments were obtained as (a) biomass of the strain from culture ( $P$. agardhii-strain SAG 6.89), and (b) biomass of the species collected from their natural habitats. A. flos-aquae and M. aeruginosa were taken during the peak of blooms. A. flos-aquae was collected from a shallow, eutrophic pond (Podkamycze 1), located close to Kraków (southern Poland; $50^{\circ} 05^{\prime} 11^{\prime \prime} \mathrm{N}, 19^{\circ} 50^{\prime} 01.6^{\prime \prime} \mathrm{E}$ ), and M. aeruginosa was collected from a shallow, eutrophic oxbow lake (Tyniec 1), located in Kraków $\left(50^{\circ} 01^{\prime} 47^{\prime \prime} \mathrm{N}\right.$, $19^{\circ} 49^{\prime} 39.8^{\prime \prime} \mathrm{E}$ ). 


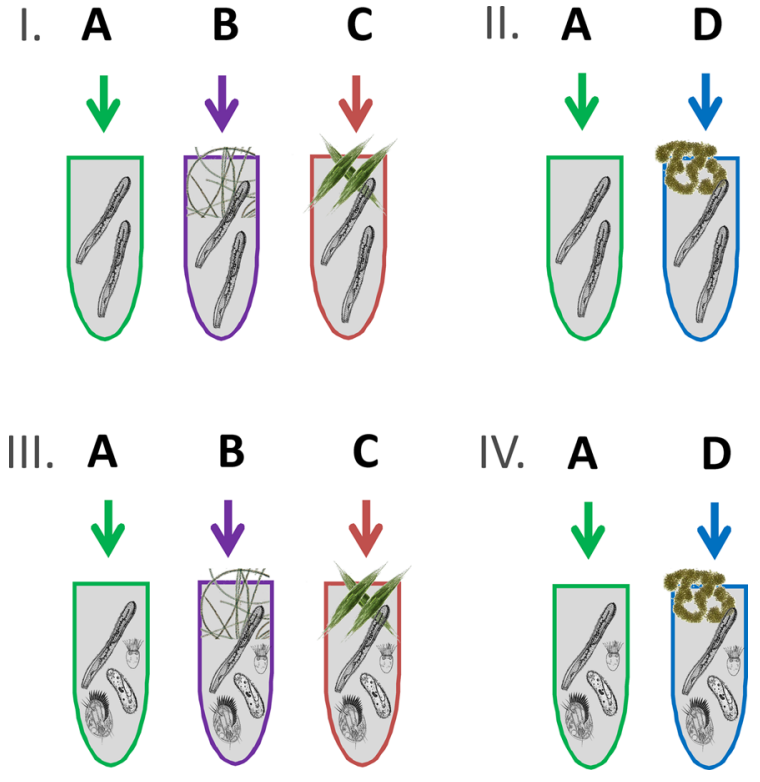

Fig. 1 Design of the experiments. I. Experiment 1. Solitary Spirostomum versus filamentous cyanobacteria-A: control sample: Spirostomum sp. + Żywiec brand mineral water; B: Spirostomum sp. + P. agardhii; C: Spirostomum sp. + A. flosaquae; II. Experiment 2. Solitary Spirostomum versus chroococcal cyanobacteria: A: control sample: Spirostomum $+\dot{Z}$ ywiec brand mineral water; D: Spirostomum sp. + M. aeruginosa; III. Experiment 3. Spirostomum in the ciliates assemblage versus filamentous cyanobacteria: A: control sample: Spirostomum in the ciliates assemblages $+\dot{Z}$ ywiec brand mineral water; B: Spirostomum as a component of assemblage + P. agardhii; $\mathrm{C}$ : Spirostomum as a component of assemblage + A. flos-aquae; IV. Experiment 4. Spirostomum in the ciliates assemblage versus chroococcal cyanobacteria: A: control sample: Spirostomum in the ciliates assemblages $+\dot{Z}$ ywiec brand mineral water; D: Spirostomum as a component of assemblage $+M$. aeruginosa

The control sample contained in Experiments 1 and 2: solitary Spirostomum cells $+\dot{Z}$ ywiec brand mineral water, and in Experiments 3 and 4: ciliates assemblage + Żywiec brand mineral water.

Planktothrix agardhii (strain SAG 6.89) was obtained from the laboratory of the Department of Hydrobiology Adam Mickiewicz University in Poznań. This strain was bought from the SAG collection in Goettingen. $P$. agardhii was cultured using the method: 'batch culture' WC medium in the cell culture flasks Greiner BioOne, at the temperature of $21^{\circ} \mathrm{C}$, and light intensity of $25 \mu \mathrm{mol} \mathrm{m} \mathrm{m}^{-2} \mathrm{~s}^{-1}$. The biomass of cyanobacteria (A. flos-aquae and $M$. aeruginosa) was concentrated from $10 \mathrm{~L}$ of water from each water body using plankton net (mesh size
$50 \mu \mathrm{m})$ during the blooms. The clonal strains of Aphanizomenon flos-aquae and Microcystis aeruginosa were isolated from the biomass of cyanobacteria. A. flos-aquae strains were maintained in modified AF6 medium (Andersen, 2001) without the addition of nitrogen compounds, and $M$. aeruginosa strains were grown in a modified MWC medium with the addition of selenium (MWC + Se; Johansson et al., 2016) under a 12:12-h light-dark cycle and at a light intensity of approximately $30 \mu \mathrm{mol} \mathrm{m} \mathrm{m}^{-2} \mathrm{~s}^{-1}$ using cool, white fluorescent illumination (Philips TL-D $36 \mathrm{~W} / 840)$ at $20^{\circ} \mathrm{C}$. The strains were deposited in the culture collection of algae and cyanobacteria at the Nature Research Centre in Vilnius (Lithuania) (Koreiviene et al., 2016). Those strains will be used for the further experiments.

In the present experiments, we wanted to imitate natural conditions; therefore, cyanobacteria were not purified from bacteria. Trichomes (A. flos-aquae) and colonies (M. aeruginosa) were picked up from samples and conditioned in the 1-1 glass beakers in water from its natural habitat under the following conditions: daylight, regime $12: 12$, temperature $21^{\circ} \mathrm{C}$, during one day. For this purpose, 51 of water from the pond for $A$. flos-aquae and 51 of water from the oxbow lake for $M$. aeruginosa were filtered using Whatman filters GF/C in order to remove all organisms. The remaining filtered water was kept in the refrigerator in sterilised glass flasks for the experiments. Before adding it to the experiments, it was kept in the laboratory atmosphere until warming up to $21^{\circ} \mathrm{C}$. Trichomes and colonies of cyanobacteria were taxonomically identified, checked for conditions (healthy/not healthy/lysis of the cells) and measured under a Nikon Eclipse 80i light microscope at a magnification of $\times 40$. The number of trichomes and colonies were counted in the 1-ml planktonic chamber with glass cover, using the same microscope equipped with a Nikon DS-Fil camera and the program NIS-Elements BR v. 3.22.12. The trichomes and colonies were healthy and in good condition. No lysis of cells were observed. They did not gather into clumps.

Spirostomum sp. was obtained from culture maintained in the Department of Hydrobiology of Jagiellonian University in Kraków, and was cultured in spring water (Żywiec Zdrój brand) and fed with buckwheat. Prior to the experiment, Spirostomum sp. cultures were maintained under the conditions: the 
daylight, regime $12: 12$, and temperature $21^{\circ} \mathrm{C}$ in a PolEko ILN 53/115/240 incubator. A simple assemblage of ciliates containing Spirostomum sp. was maintained in the laboratory of the Institute of Nature Conservation, cultured in spring water (Żywiec Zdrój brand) and fed with straw.

Because the blooms of $A$. flos-aquae and $M$. aeruginosa were created at different times, we set up two experiments as follows: Experiments 1 and 3 tested the effect only of the filamentous species, $P$. agardhii and A. flos-aquae (Fig. 1; I and III), and Experiments 2 and 4 tested the effect of the chroococcal species-M. aeruginosa (Fig. 1; II and IV).

The experiment was performed in Corning ${ }^{\circledR}$ Cell Wells containing $10 \mathrm{ml}$ of medium. The medium was used as follow: (a) for control samples-spring water (Żywiec Zdrój brand); (b) for samples with $P$. agardhii-filtered water from culture containing $P$. agardhii; (c) for samples with A. flos-aquae-filtered water from the pond (natural habitat); and (d) for samples with $M$. aeruginosa-filtered water from the oxbow lake (natural habitat).

Every well was fed the similar number of ciliates (150 individuals of Spirostomum in the first and second experiments and 10-40 individuals of Spirostomum in the third and fourth experiments), and cyanobacteria trichomes or colonies ( $P$. agardhii 50,000 trichomes $\mathrm{ml}^{-1}$; A. flos-aquae 660,000 trichomes $\mathrm{ml}^{-1}$; M. aeruginosa 40,000 colonies $\mathrm{ml}^{-1}$ ), which were filled with drops of the incubated culture using pipets.

The assemblage of ciliates contained four species (Spirostomum sp., Euplotes patella, Strobilidium sp. and Paramecium aurelia-complex). The ciliates were fed at the beginning of the experiment ( 0 day): each well was inserted with 1 grain of buckwheat (experiments with solitary Spirostomum) or a blade of straw $(1 \mathrm{~cm}$; experiments with simple assemblages of ciliates).

Because microcystins are stable in the dark (Chorus \& Bartram, 1999), in order to keep the cyanotoxins stable for as long as possible, we decided to perform the experiments in the dark. The experiments were kept at a constant temperature of $21^{\circ} \mathrm{C}$. Each experiment was performed in triplicate. The experiments were conducted over 14 days. The plates with cells were constantly gently shaken. Individuals of ciliates were counted on the following days: $0,3 \mathrm{rd}, 7 \mathrm{th}, 10 \mathrm{th}$ and 14th. Samples for ciliates counting were taken by micropipets $(1 \mathrm{ml})$. The cells were fixed by adding Lugol's iodine solution and were not returned to the wells. The number of cells was counted under the Nikon Eclipse 80i light microscope at a magnification of $\times 20$ in the $1-\mathrm{ml}$ planktonic chamber with glass cover.

In order to obtain knowledge about the concentration of microcystins, an analysis of toxins in the cyanobacteria cells and dissolved in the water was performed. Because A. flos-aquae are able to produce anatoxin-a, we also checked A. flos-aquae for its presence. For the analysis of toxins (microcystins and anatoxin-a) in the cyanobacterial cells, HPLC analyses were conducted. Immediately after sampling, 1-1 samples of water containing cyanobacteria (samplings were done at the same places and time as was done while gathering the cyanobacteria biomass), and 1-1 samples of water from the Planktothrix culture were filtered through Whatman filters GF/C. For a detailed description of the method and equipment used for the analysis, see Kaczkowski et al. (2017).

For the microcystins dissolved in the water, we used 1-1 samples of water from the $P$. agardhii culture and water collected from the pond and oxbow lake. 1-1 water samples were filtered using Whatman GF/C filter papers to separate cyanobacterial cells from the water. Extracellular microcystins were concentrated in Baker $\mathrm{C}_{18}$ solid-phase extraction (SPE) cartridges (Deventer, Netherlands; sorbent mass: $500 \mathrm{mg}$ ) and eluted using $90 \% \mathrm{MeOH}$ containing $0.1 \%$ trifluoroacetic acid (TFA) according to the methods of Meriluoto \& Codd (2005).

The microcystins were analysed using an Agilent 1100 apparatus with a diode matrix (DAD) (Quinn \& Keough, 2002). The concentrations of microcystins dissolved in the water were determined in the Central Laboratory of the Municipal Water and Sewage Company in Kraków, Poland. In both cases, the microcystins were identified using the microcystin standards MC-LR, MC-RR and MC-YR based on their characteristic absorption spectra and retention times.

Intra- and extracellular toxins were measured in biomass and in the same water used for the experiments.

Statistics We used a generalized linear model (GLM) to test the relationship and differences among the relationships between Spirostomum sp. and different species of potentially toxic cyanobacteria. The 
generalized linear model (GLM) is an extension of the simple linear regression model for a continuous response variable given one or more continuous and/ or categorical predictors. It includes multiple linear regression, as well as analysis of variance and analysis of covariance (Quinn \& Keough, 2002). We calculated the GLM using the Poisson distribution; the dependent variables were a) cyanobacteria species and b) cyanobacteria species + day of experiment. Plots of the predicted values were created using the 'ggeffects' package (Lüdecke, 2017). Data were considered statistically significant at $P<0.05$. All statistical analyses were performed by means of $\mathrm{R}$ v. 3.4.2 (R Core Team, 2017).

\section{Results}

The biomass of cyanobacteria used for the experiments showed the presence of microcystins for $P$. agardhii and M. aeruginosa, but not for A. flos-aquae. We did not find demethylated variants of microcystins in the $P$. aghardii biomass and also did not find anatoxin-a in the biomass of A. flos-aquae (Table 1). Microcystins were present as three analogues: microcystin-LR (MC-LR), microcystin-RR (MC-RR) and microcystin-YR (MC-YR). In the Microcystis aeruginosa cells, MC-LR and MC-RR were having a similar concentration, but in the Planktothrix agardhii cells, the highest concentration was found for MC-RR. The strain of $P$. agardhii was highly toxic.

Microcystins were also found as dissolved in the water from the $P$. agardhii culture and in the water from the oxbow lakes where $M$. aeruginosa bloomed, but not in the water from the pond where A. flos-aquae bloomed (Table 1).
The Spirostomum sp. population versus biomasses of different species of cyanobacteria

In the experiments, we examined the effects of toxic and non-toxic cyanobacteria biomasses on the population of Spirostomum as solitary species (Experiments 1-filamentous cyanobacteria and 2chroococcal cyanobacteria; for the experiment description, see "Materials and methods" and Fig. 1).

The GLM showed an increase in the number of Spirostomum individuals in the control sample (no cyanobacteria, no toxins) and in the sample with highly toxic $P$. agardhii, but a decrease in the sample with nontoxic A. flos-aquae (Experiment 1, Table 2, Fig. 2A). In the second experiment, the GLM analysis showed stable populations of Spirostomum (Table 2) in the control sample (no cyanobacteria, no toxins), and an increase in the number of Spirostomum individuals in the sample with toxic M. aeruginosa (Table 2, Fig. 2B).

The number of Spirostomum individuals changed in the samples with the presence of particular cyanobacteria species (Table 2). All the differences were statistically significant except for the experiment with A. flos-aquae (Table 2). We also found strong statistical differences in the number of Spirostomum individuals in the presence of cyanobacteria species over time (Table 2). The number of Spirostomum individuals increased over time in the samples with $P$. agardhii and $M$. aeruginosa, but decreased in the sample with A. flos-aquae (Fig. 2A and 2B).

Spirostomum sp. as a component of ciliate assemblages versus cyanobacteria

In these experiments, we examined the effect of cyanobacteria biomass on Spirostomum as a component of a simple ciliate assemblage consisting of four species (Experiments 3-filamentous cyanobacteria and 4 - chroococcal cyanobacteria).

Table 1 Concentrations of microcystins $(\mu \mathrm{g} / \mathrm{l})$ in the cells of cyanobacteria and dissolved in the water used for the experiments

\begin{tabular}{llrrrrr}
\hline Number of experiment & Sample & MC-RR (in cells) & MC-YR (in cells) & MC-LR (in cells) & \multicolumn{2}{c}{ MC-tot } \\
\cline { 3 - 7 } & & & & In cells & Dissolved in water \\
\hline 1,3 & P. agardhii & 282.6 & 11.9 & 29.4 & 323.9 & 29.9 \\
1,3 & A. flos-aquae & 0.0 & 0.0 & 0.0 & 0.0 & 0.0 \\
2,4 & M. aeruginosa & 14.3 & 2.8 & 14.8 & 31.9 & 0.4 \\
\hline
\end{tabular}


Table 2 Results of the generalized linear model (GLM) for solitary Spirostomum sp.

Estimates of the GLM coefficients and their standard errors (SE) are presented. Z-GLM test statistic, $P$-statistical significance are emboldened

\begin{tabular}{lrrrr}
\hline Treatment & Estimate & \multicolumn{1}{l}{ SE } & \multicolumn{1}{l}{$Z$} & \multicolumn{1}{l}{$P$} \\
\hline Intercept (Control 1) Experiment 1 & 5.030 & 0.031 & 159.654 & $<\mathbf{0 . 0 0 1}$ \\
Planktothrix 1 & -0.427 & 0.045 & -9.343 & $<\mathbf{0 . 0 0 1}$ \\
Aphanizomenon 1 & -0.164 & 0.058 & -2.798 & $<\mathbf{0 . 0 1}$ \\
Control 1: day & 0.087 & 0.003 & 28.057 & $<\mathbf{0 . 0 0 1}$ \\
Planktothrix 1: day & 0.088 & 0.004 & 20.802 & $<\mathbf{0 . 0 0 1}$ \\
Aphanizomenon 1: day & -0.612 & 0.028 & -21.360 & $<\mathbf{0 . 0 0 1}$ \\
Intercept (Control 2) Experiment 2 & 5.600 & 0.027 & 205.899 & $<\mathbf{0 . 0 0 1}$ \\
Microcystis 2 & -0.161 & 0.034 & -4.676 & $<\mathbf{0 . 0 0 1}$ \\
Control 2: day & -0.018 & 0.003 & -5.525 & $<\mathbf{0 . 0 0 1}$ \\
Microcystis 2: day & 0.207 & 0.003 & 53.680 & $<\mathbf{0 . 0 0 1}$ \\
\hline
\end{tabular}

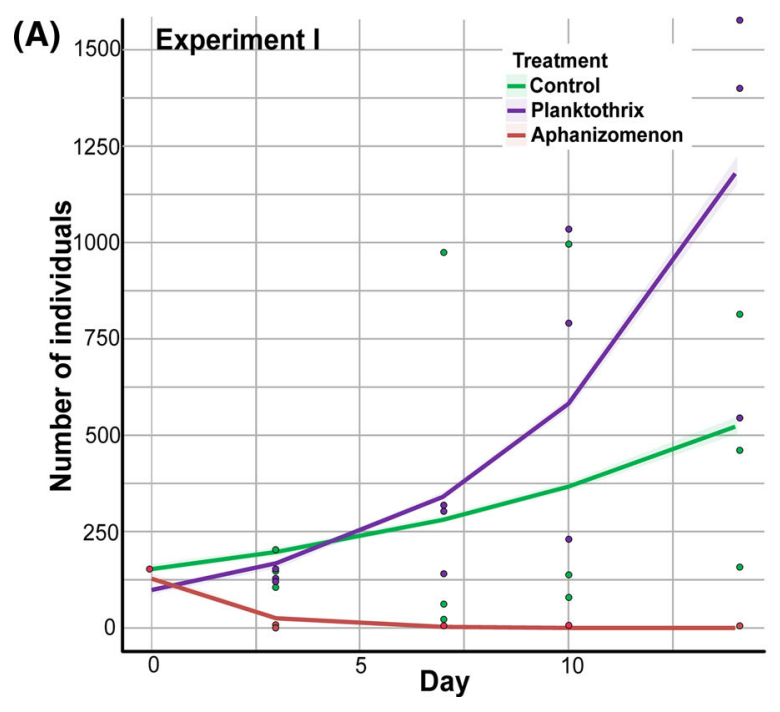

Fig. 2 The predicted number of individuals for Spirostomum sp. (solitary specimen): (A) Experiment 1: green line and dotscontrol sample, violet line and dots-sample with the addition of $P$. agardhii, red line and dots-sample with the addition of $A$.

The GLM analysis showed a decrease of the Spirostomum population being a component of ciliate assemblages in the presence of cyanobacteria, for both toxic and non-toxic types (Fig. 3A, B).

The statistically significant differences were found for the number of Spirostomum individuals being a component of ciliate assemblage in the presence of $A$. flos-aquae (non-toxic) and M. aeruginosa (toxic), but not in the presence of $P$. agardhii (highly toxic, Table 3). A statistically significant decrease of the number of Spirostomum individuals in time was observed in the presence of all three species of cyanobacteria. The strongest decrease was found for

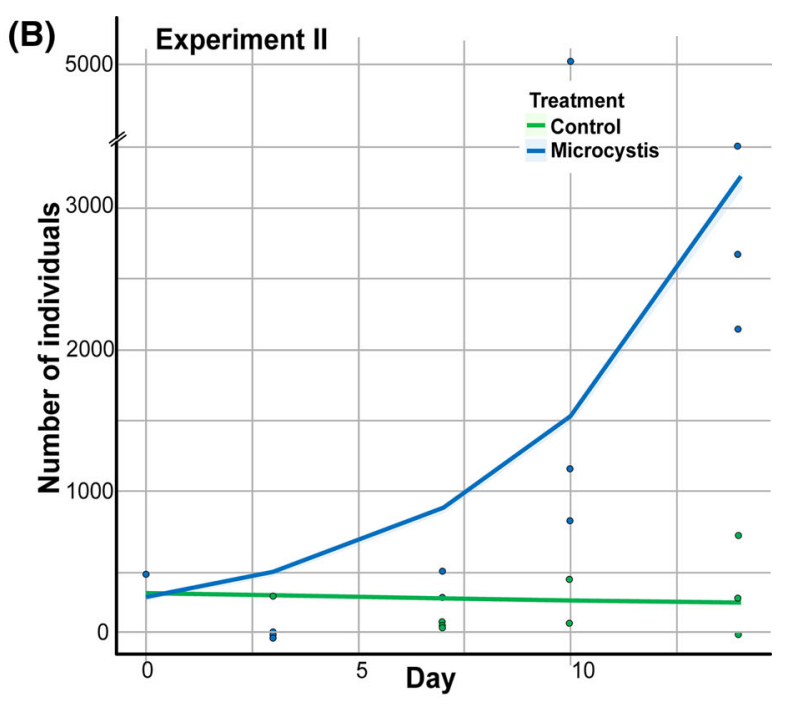

flos-aquae; (B) Experiment 2: green line and dots-control sample, blue line and dots-sample with the addition of $M$. aeruginosa

A. flos-aquae, a weaker one for P. agardhii, and the weakest for $M$. aeruginosa (Table 3).

We observed weak but significant decrease of Euplotes patella (Table 4, Fig. 4, Supplementary material) over time in the presence of $P$. agardhii and weak and also significant increase of E. patella in the presence of A. flos-aquae and M. aeruginosa. For Strobilidium sp. (Table 5, Fig. 5, Supplementary material), we observed weak and significant decrease in the presence of A. flos-aquae and P. agardhii, but increase in the presence of $M$. aeruginosa. However, for Paramecium aurelia-complex (Table 6, Fig. 6, Supplementary material), we found statistically significant increase in the presence of A. flos-aquae and 


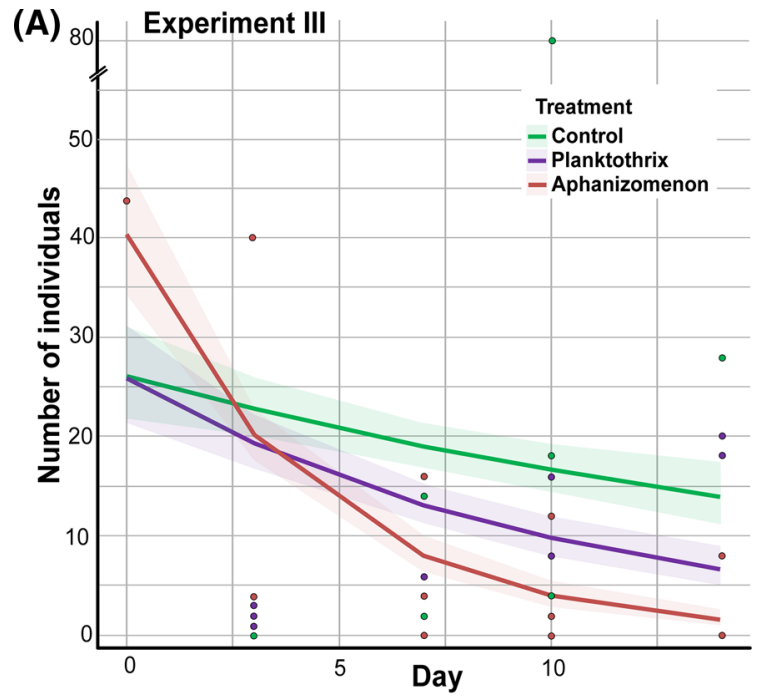

Fig. 3 The predicted number of individuals of Spirostomum sp. (as a component of ciliate assemblage): (A) Experiment 3: green line and dots-control sample, violet line and dots-sample with the addition of $P$. agardhii, red line and dots-sample with

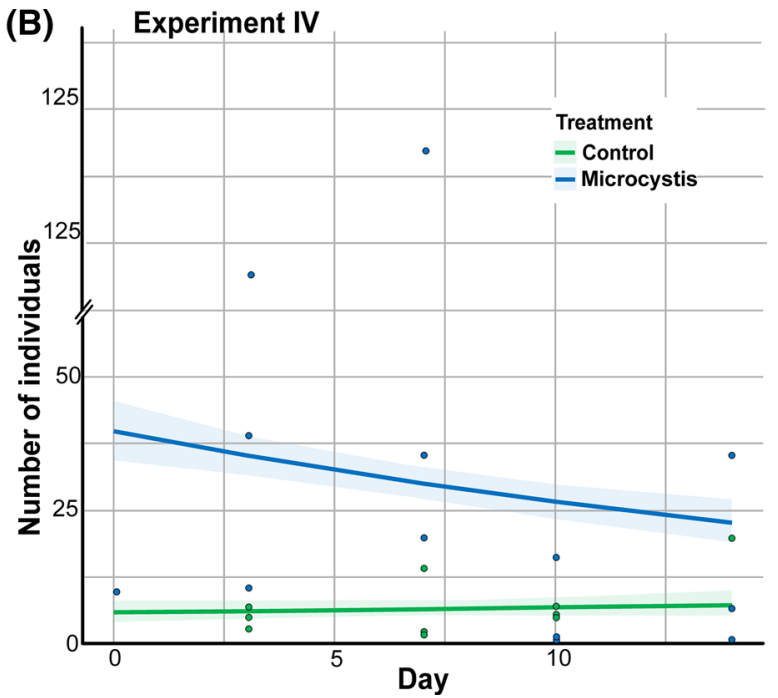

the addition of A. flos-aquae; (B) Experiment 4: green line and dots-control sample, blue line and dots-sample with the addition of $M$. aeruginosa

Table 3 Results of the generalized linear model (GLM) for Spirostomum sp.

\begin{tabular}{|c|c|c|c|c|}
\hline Sample & Estimate & SE & $Z$ & $P$ \\
\hline Intercept (Control 1) Experiment 3 & 3.259 & 0.090 & 36.187 & $<\mathbf{0 . 0 0 1}$ \\
\hline Planktothrix 1 & -0.006 & 0.130 & -0.047 & 0.962 \\
\hline Aphanizomenon 1 & 0.436 & 0.122 & 3.577 & $<\mathbf{0 . 0 0 1}$ \\
\hline Control 1: day & -0.044 & 0.012 & -3.728 & $<\mathbf{0 . 0 0 1}$ \\
\hline Planktothrix 1: day & -0.052 & 0.018 & -2.767 & $<\mathbf{0 . 0 1}$ \\
\hline Aphanizomenon 1: day & -0.186 & 0.023 & -8.046 & $<\mathbf{0 . 0 0 1}$ \\
\hline Intercept (Control 2) Experiment 4 & 1.760 & 0.178 & 9.854 & $<0.001$ \\
\hline Microcystis 2 & 1.923 & 0.192 & 9.977 & $<\mathbf{0 . 0 0 1}$ \\
\hline Control 2: day & 0.015 & 0.020 & 0.745 & 0.456 \\
\hline Microcystis 2: day & 0.0554 & 0.022 & -2.454 & $<0.05$ \\
\hline
\end{tabular}

Spirostomum sp. being a component of ciliate assemblage. Estimates of the GLM coefficients and their standard errors (SE) are presented. $Z$ - GLM test statistic, $P$ - statistical significance are emboldened

P. agardhii but no significant changes in the presence of $M$. aeruginosa.

\section{Discussion}

The toxic effect of cyanotoxins on vertebrates is well known, but they are also harmful for invertebrates, e.g. planktonic animals, and may be responsible for the appearance of clonal subpopulations of invertebrates such as Daphnia sp. (e.g. Schwarzenberger et al., 2013). Although planktonic animals are subjected to cyanotoxins because of the uptake of toxic cells, toxins dissolved in the water may also have a negative effect (Reinikainen et al., 2002), because some microcystin congeners may cross cell membranes by other mechanisms, including diffusion (Chorus \& Bartram, 1999).

There are no clear responses of zooplankton to cyanotoxins, and especially of ciliates. Information in 
the literature is contradictory: for example, the toxicities of Fischerella epiphytica, Gleotrichia echinulata and Nostoc linckia were demonstrated to Paramecium caudatum (Ransom et al., 1978). On the other hand, a different response of Tetrahymena pyriformis to microcystins (Ward \& Codd, 1999) was shown, with no lethal effect of microcystins to Nassula sp. that grazed on toxic Planktothrix agardhii (Combes et al., 2013). Nassula sp. is also considered as a species grazing on Aphanizomenon and Anabaena and may reduce cyanobacterial blooms (Canter et al., 1990). Also, Paramecium cf. caudatum was found to be a successful grazer of toxin-producing Cylindropsermopsis (Fabbro et al. 2001). However, cyanobacteria-ciliates relationships might be modyfied because of differences in cyanobacteria cells, shape and size, which determine the capability of defending cyanobacteria themselves against protozoan grazers (Pajdak-Stós et al., 2001; Fiałkowska \& Pajdak-Stós, 2014).

Our studies indicate that microcystins in cells and dissolved in water do not harm ciliates, even when concentrations of toxins are high. On the other hand, some studies reported that the high toxicity of extract containing anatoxin-a was harmful to Tetrahymena thermophila (Sierosławska et al., 2010). It illustrates that cyanotoxin-ciliate relationships should be studied as species-specific phenomena. Our studies also showed that the abundance of Spirostomum sp. increased in the presence of toxic cyanobacteria with a high to extremely high concentration of microcystins in the cells and also with high concentrations of microcystins dissolved in the water. On the other hand, the abundance of Spirostomum decreased in the presence of A. flos-aquae, strain which did not produce either microcystins or anatoxin-a. These results indicate that the factor that negatively affected Spirostomum was neither the presence nor the high concentration of toxins (microcystins, anatoxin-a). In such a case, it might be another direct factor such as the presence of different kinds of metabolites produced by A. flos-aquae (̌̌ezanka \& Dembitsky, 2006) that affected Spirostomum abundance, or some other indirect factor. In our opinion, a better explanation of this phenomenon is the indirect relation between cyanobacteria and ciliates. There are known ciliatesbacteria relationships but they are not well understood (Boscaro et al., 2018). Cyanobacterial bloom may significantly induce an increase in bacterial production (Kuosa \& Kivi, 1989), which could be a food source for bacterivorous ciliates, e.g. Spirostomum. Bacteria growing up on different cyanobacteria species might be specific, and may inhibit the growth of specific ciliates species. Pearman et al. (2016) observed that the bacterial and protists community changed because of cyanobacterial bloom. At least, some species of ciliates appear to selectively feed upon other bacteria if offered a choice (Caron et al., 1991).

Another indirect relation might be an effect of the ability of cyanobacteria to produce biologically active compounds with cyanotoxins showing antibacterial, antiviral, antifungal, and anticancer activities (Bhateja et al., 2006). In such a case, the toxic species are responsible for destroying some adverse microorganisms (viruses, bacteria, pathogens, etc.) that promote the development of some species of ciliates. Antibacterial activity changes according to the cyanobacteria species. These bioactive substances may possibly lead to specific bacterial flora affecting the composition of bacterial communities (Skulberg, 2000) and, as a consequence, promoting the development or decrease of specific species of ciliates.

An increase of ciliates abundance in the presence of toxic cyanobacteria is possible due to some aquatic bacteria having the ability to metabolise high MC concentrations; MCs are a source of dissolved organic carbon for bacteria, which enables an increase of the bacteria's population (Sellner, 1997; Sopanen et al., 2009) and, as a consequence, ciliates. On the contrary, a lack of toxins will cause a decrease of bacteria and, furthermore, a decrease of ciliates.

Bacterial growth can be also limited when nitrogen limitation occurs (Casamatta \& Wickstrom, 2000). The presence of A. flos-aquae indicates a deficiency of nitrogen in the water and may indicate a scarcity of bacteria, explaining the decrease of Spirostomum abundance.

The indirect relation between Spirostomum and cyanobacteria is confirmed by the experiment with simple assemblage of ciliates versus toxic/non-toxic cyanobacteria species. In this experiment, Spirostomum abundance decreased in the presence of toxic ( $M$. aeruginosa, $P$. agardhii) and non-toxic (A.flos-aquae) cyanobacteria. This trend indicates an effect of competition between Spirostomum and the remaining smaller ciliates species (Euplotes patella and Strobilidium sp. in the presence of M. aeruginosa, and Paramecium aurelia-complex and E. patella in the presence of A. flos-aquae, but Paramecium aurelia- 
complex in the presence of $P$. agardhii) that feed more effectively (compared with the large Spirostomum) on bacteria (Christoffersen et al., 1990). In a shallow lake in Denmark, the importance of small ciliates as transformers of carbon from bacteria growing after Aphanizomenon bloom was found (Christoffersen et al., 1990).

In general, we found that the reaction of solitary species of ciliates (Spirostomum) to the presence of toxic cyanobacteria is not the same as Spirostomum being a component of ciliates assemblage. Spirostomum as a single species did not show a negative response to toxic cyanobacteria and toxins dissolved in the water. On the other hand, a decrease of Spirostomum abundance being in the ciliate assemblage might be an effect of competition between different species of ciliates. However, our observation is contrary to the one that was shown by Tirjaková et al. (2016) in a small eutrophic pond. In those studies, Spirostomum dominated among ciliate communities during cyanobacterial bloom, along with Euplotes and Paramecium which were also used in our experiments. Therefore, Tirjaková et al. (2016) stated that Spirostomum can be considered as a good competitor in natural communities, also possibly because it is microaerophilic and can withstand under a wide range of oxic/anoxic conditions (literature cited in Tirjaková et al., 2016). In the above-mentioned studies, Spirostomum abundances were positively correlated with Euplotes abundances, which is also opposite to our observation. The differences might be explained by different food preferences and/or by a broader range of food sources in the macrocosm (e.g. the presence of different species of bacteria, etc.), and/ or by different structures of ciliates communities (e.g. the presence more species in the pond), and/or by the presence of metazooplankton which may effect ciliates (in pond) or lack of it (in the experiment).

Finally, the results of our studies show that cyanobacterial blooms affected ciliates not necessarily as a direct result of toxins-ciliates relationships, but because cyanobacteria and toxins induce changes in the water food network.

\section{Conclusions}

In conclusion, toxic cyanobacteria may positively or negatively affect the Spirostomum population (and other ciliates species) not only because of direct toxic effect but because of indirect interaction as well.

The same species of ciliates may react in a different way to the presence of cyanobacterial blooms, not only because of cyanotoxins but also because of ciliate assemblages composition and the competition between species and the existence of species-specific interactions (e.g. ciliates-ciliates, ciliates-cyanobacteria, ciliates-bacteria).

Acknowledgements The present study was supported by the Institute of Nature Conservation, Polish Academy of Sciences as a statutory activity and as a grant for Young Scientists for J. Kosiba; and by the Institute of Botany, Polish Academy of Sciences as a grant for PhD students granted for J. Kosiba. The authors would like to thank senior researcher J. Koreiviené, $\mathrm{PhD}$ (Nature Research Centre, Vilnius, Lithuania) for the isolation of cyanobacterial strains and keeping them in the algal and cyanobacterial culture; the $\mathrm{PhD}$ students: M. Sobczyk (Jagiellonian University) and $Ł$. Wejnerowski (Adam Mickiewicz University in Poznan) for their sharing of ciliates and cultures of P. agardhii; Prof. P. Skórka and Prof. D. Chmura for consultation with statistical analyses; and E. Walusiak, PhD for help in the field samples collection. The analysis of cyanotoxins in biomass was performed by T. Jurczak, PhD (Department of Applied Ecology, University of Łódź), and in water by K. Pudaś (Municipal Water and Sewage Company, Kraków). We would also like to thank anonymous reviewers for sharing your doubts and valuable comments and suggestions.

\section{Compliance with ethical standards}

Conflict of interest The authors declare that they have no conflict of interest.

Open Access This article is distributed under the terms of the Creative Commons Attribution 4.0 International License (http:// creativecommons.org/licenses/by/4.0/), which permits unrestricted use, distribution, and reproduction in any medium, provided you give appropriate credit to the original author(s) and the source, provide a link to the Creative Commons license, and indicate if changes were made.

\section{References}

Andersen, R. A., 2001. Algal Culturing Techniques. Elsevier, Amsterdam.

Bhateja, P., T. Mathur, M. Pandya, T. Fatma \& A. Rattan, 2006. Activity of blue green microalgae extracts against in vitro generated Staphylococcus aureus with reduced susceptibility to vancomycin. Fitoterapia 77: 233-235.

Boscaro, V., S. I. Fokin, G. Petroni, F. Verni, P. J. Keeling \& C. Vannini, 2018. Symbiont replacement between bacteria of different classes reveals additional layers of complexity in 
the evolution of symbiosis in the ciliate Euplotes. Protist 169(1): 43-52.

Buratti, F. M., M. Manganelli, S. Vichi, M. Stefanelli, S. Scardala, E. Testai \& E. Funari, 2017. Cyanotoxins: producing organisms, occurrence, toxicity, mechanism of action and human health toxicological risk evaluation. Archives of Toxicology 91(3): 1049-1130.

Canter, H. M., S. I. Heaney \& J. W. G. Lund, 1990. The ecological significance of grazing on planktonic populations of cyanobacteria by the ciliate Nassula. New Phytologist 114(2): 247-263.

Carmichael, W. W., 1992. Cyanobacteria secondary metabolites - the cyanotoxins. Journal of Applied Bacteriology 72(6): 445-459.

Carmichael, W. W., 1994. The toxins of cyanobacteria. Scientific American 270: 78-86.

Caron, D. A., E. L. Lim, G. Miceli, J. B. Waterbury \& F. W. Valois, 1991. Grazing and utilization of chroococcoid cyanobacteria and heterotrophic bacteria by a protozoa in laboratory cultures and a coastal plankton community. Marine Ecology Progress Series 76(3): 205-217.

Casamatta, D. A. \& C. E. Wickstrom, 2000. Sensitivity of two disjunct bacterioplankton communities to exudates from the cyanobacterium Microcystis aeruginosa Kützing. Microbial Ecology 40(1): 64-73.

Chorus, L. \& J. Bartram, 1999. Toxic Cyanobacteria in Water. E\&FN Spon, London/New York.

Christoffersen, K., B. Riemann, L. R. Hansen, A. Klysner \& H. B. Sørensen, 1990. Qualitative importance of the microbial loop and plankton community structure in a eutrophic lake during a bloom of cyanobacteria. Microbial Ecology 20(1): 253-272.

Codd, G. A., C. Edwards, K. A. Beattie, L. A. Lawton, D. L. Campbell \& S. G. Bell, 1995. Toxins from cyanobacteria (blue-green algae). In Wiessner, W., E. Schnepf \& R. C. Starr (eds), Algae, Environment and Human Affairs. Biopress Ltd., Bristol: 1-17.

Codd, G. A., L. F. Morrison \& J. S. Metcalf, 2005. Cyanobacterial toxins: risk management for health protection. Toxicology and Applied Pharmacology 203(3): 264-272.

Combes, A., M. Dellinger, S. Cadel-six, S. Amand \& K. Comte, 2013. Ciliate Nassula sp. grazing on a microcystin-producing cyanobacterium (Planktothrix agardhii): impact on cell growth and in the microcystin fractions. Aquatic Toxicology 126: 435-441.

Fabbro, L., M. Baker, L. Duivenvoorden, G. Pegg \& R. Shiel, 2001. The effects of the ciliate Paramecium cf. caudatum Ehrenberg on toxin producing Cylindrospermopsis isolated from the Fitzroy River, Australia. Environmental Toxicology 16(6): 489-497.

Ferrão-Filho, A. D. \& B. Koslowsky-Suzuki, 2011. Cyanotoxins: bioaccumulation and effects on aquatic animals. Marine Drugs 9: 2729-2772.

Fiałkowska, E. \& A. Pajdak-Stós, 2014. Chemical and mechanical signals in inducing Phormidium (Cyanobacteria) defence against their grazers. FEMS Microbiology Ecology 89(3): 659-669.

Gołdyn, R., E. Szeląg-Wasielewska, K. KowalczewskaMadura, R. Dondajewska, A. Budzyńska, S. Podsiadłowski, P. Domek \& W. Romanowicz-Brzozowska, 2010. Functioning of the Lake Rusałka ecosystem in
Poznań (western Poland). Oceanological and Hydrobiological Studies 39(3): 65-80.

Havens, K. E., 1998. Size structure and energetics in a plankton food web. Oikos 81: 346-358.

Ibelings, B. W., K. Bruning, J. Jonge, K. Wolfstein, D. Pires, J. Postma \& T. Burger, 2005. Distribution of microcystins in a lake foodweb: no evidence for biomagnification. Microbial Ecology 49(4): 487-500.

Johansson, K. S., K. Luhrig, J. Klaminder \& K. Rengefors, 2016. Development of a quantitative PCR method to explore the historical occurrence of a nuisance microalga under expansion. Harmful Algae 56: 67-76.

Kaczkowski, Z., A. Wojtal-Frankiewicz, I. Gągała, J. Mankiewicz-Boczek, A. Jaskulska, P. Frankiewicz, K. Izydorczyk, T. Jurczak \& M. Godlewska, 2017. Relationships among cyanobacteria, zooplankton and fish in sub-bloom conditions in the Sulejow Reservoir. Journal of Limnology 76(2): 380-396.

Koreivienė, J., J. Kasperovičienė, K. Savadova, J. Karosienė \& I. Vitonyte, 2016. Collection of pure cultures of algae and cyanobacteria for research, teaching and biotechnological applications (Nature Research Centre, Lithuania). Botanica Lithuanica 22: 87-92.

Kosiba, J., W. Krztoń \& E. Wilk-Woźniak, 2018. Effect of microcystins on proto-and metazooplankton is more evident in artificial than in natural waterbodies. Microbial Ecology 75: 293-302.

Koslowsky-Suzuki, B., A. E. Wilson \& A. S. Ferrão-Filho, 2012. Biomagnification or biodilution of microcystins in aquatic foodwebs? Meta-analyses of laboratory and field studies. Harmful Algae 18: 47-55.

Kuosa, H. \& K. Kivi, 1989. Bacteria and heterotrophic flagellates in the pelagic carbon cycle in the northern Baltic Sea. Marine Ecology Progress Series 53: 93-100.

Lampert, W., 1987. Laboratory studies on zooplanktoncyanobacteria interactions. New Zealand Journal Marine Freshwater Research 21(3): 483-490.

Lüdecke, D., 2017. ggeffects: Create Tidy Data Frames of Marginal Effects for 'ggplot' from Model Outputs. R package version 0.3.0. https://CRAN.R-project.org/ package $=$ ggeffects.

Mantzouki, E., M. Lürling, J. Fastner, L. de Senerpont Domis, E. Wilk-Woźniak, J. Koreiviene, et al., 2018. Temperature effects explain continental scale distribution of cyanobacterial toxins. Toxins 10(4): 156.

Maršálek, B. \& L. Bláha, 2004. Comparasion of 17 biotests for detection of cyanobacterial toxicity. Environmental Toxicology 19: 310-317.

Martins, J., L. Peixe \& V. M. Vasconcelos, 2011. Unraveling cyanobacteria ecology in wastewater treatment plants (WWTP). Microbial Ecology 62(2): 241-256.

Meriluoto, J. \& G. A. Codd, 2005. Toxic: Cyanobacterial monitoring and cyanotoxin analysis. Acta Academiae Aboensis 65(1): 1-149.

Pajdak-Stós, A., E. Fiałkowska \& J. Fyda, 2001. Phormidium autumnale (Cyanobacteria) defense against three ciliate grazer species. Aquatic Microbial Ecology 23(3): 237-244.

Pearman, J. K., L. Casas, T. Merle, C. Michell \& X. Irigoien, 2016. Bacterial and protist community changes during a phytoplankton bloom. Limnology and Oceanography 61(1): 198-213. 
Quinn, G. P. \& M. J. Keough, 2002. Experimental Design and Data Analysis for Biologists. Cambridge University Press, Cambridge.

R Core Team, 2017. A language and environment for statistical computing. R Foundation for Statistical Computing, Vienna, Austria. https://www.R-project.org/.

Ransom, R. E., T. A. Nerad \& P. G. Meier, 1978. Acute toxicity of some bluegreen algae to the protozoan Paramecium caudatum. Journal of Phycology 14: 114-116.

Rapala, J., K. Sivonen, C. Lyra \& S. I. Niemelä, 1997. Variation of microcystins, cyanobacterial hepatotoxins, in Anabaena spp. as a function of growth stimuli. Applied and Environmental Microbiology 63: 2206-2212.

Reinikainen, M., F. Lindvall, J. A. O. Meriluoto, S. Repka, K. Sivonen, L. Spoof \& M. Wahlsten, 2002. Effects of dissolved cyanobacterial toxins on the survival and egg hatching of estuarine calanoid copepods. Marine Biology 140: 577-583.

Řezanka, T. \& V. M. Dembitsky, 2006. Metabolites produced by cyanobacteria belonging to several species of the family Nostocaceae. Folia Microbiologica 51(3): 159-182.

Rohrlack, T. \& P. Hyenstrand, 2007. Fate of intracellular microcystins in the cyanobacterium Microcystis aeruginosa (Chroococcales, Cyanophyceae). Phycologia 46(3): 277-283.

Schwarzenberger, A., S. D'Hondt, W. Vyverman \& E. von Elert, 2013. Seasonal succession of cyanobacterial protease inhibitors and Daphnia magna genotypes in a eutrophic Swedish lake. Aquatic Sciences 75(3): 433-445.

Sellner, K. G., 1997. Physiology, ecology, and toxic properties of marine cyanobacterial blooms. Limnology and Oceanography 42: 1089-1104.

Sherr, E. B. \& B. F. Sherr, 1994. Bacterivory and herbivory: key roles of phagotrophic protists in pelagic food webs. Microbial Ecology 28: 223-235.

Sierosławska, A., A. Rymuszka, R. Kalinowska, T. Skowroński, A. Bownik \& B. Pawlik-Skowrońska, 2010. Toxicity of cyanobacterial bloom in the eutrophic dam reservoir (Southeast Poland). Environmental Toxicology and Chemistry 29(3): 556-560.

Sivonen, K. \& G. Jones, 1999. Cyanobacterial toxins. In Chorus, I. \& J. Bartram (eds), Toxic Cyanobacteria in Water: A Guide to their Public Health Consequences, Monitoring and Management. E\&FN Spon, London and New York: 43-112.

Skulberg, O. M., 2000. Microalgae as a source of bioactive molecules - experience from cyanophyte research. Journal of Applied Phycology 12: 341-348.

Sommer, U., R. Adrian, L. De Senerpont Domis, J. J. Elser, U. Gaedke, B. Ibelings, E. Jeppesen, M. Lürling, J. C. Molinero, W. M. Mooij \& E. Van Donk, 2012. Beyond the Plankton Ecology Group (PEG) model: mechanisms driving plankton succession. Annual Review of Ecology, Evolution, and Systematics 43: 429-448.

Sopanen, S., P. Uronen, P. Kuuppo, C. Svensen, A. Rühl, T. Tamminen, E. Granéli \& C. Legrand, 2009. Transfer of nodularin to the copepod Eurytemora affinis through the microbial food web. Aquatic Microbial Ecology 55(2): $115-130$.

Tarczyńska, M., G. Nałęcz-Jawecki, Z. Romanowska-Duda, J. Sawicki, K. Beattie, G. Codd \& M. Zalewski, 2001. Tests for the toxicity assessment of cyanobacterial bloom samples. Environmental Toxicology 16(5): 383-390.

Tirjaková, E., K. Krajčovičová, M. Illyová \& P. Vd'ačný, 2016. Interaction of ciliate communities with cyanobacterial water bloom in a shallow, hypertrophic reservoir. Acta Protozoologica 3: 173-188.

Ward, C. J. \& G. A. Codd, 1999. Comparative toxicity of four microcystins of different hydrophobicities to the protozoan, Tetrahymena pyriformis. Journal of Applied Microbiology 86: 874-882.

Wilson, A. E., O. Sarnelle \& A. R. Tillmanns, 2006. Effects of cyanobacterial toxicity and morphology on the population growth of freshwater zooplankton: meta-analyses of laboratory experiments. Limnology and Oceanography 51(4): 1915-1924.

Zaccaroni, A. \& D. Scaravelli, 2008. Toxicity of fresh water algal toxins to humans and animals. In Evangelista, V., L. Barsanti, A. M. Frassanito, V. Passarelli \& P. Gualtieri (eds), Algal Toxins: Nature, Occurrence, Effect and Detection. Springer, Dordrecht: 45-89.

Zurawell, R. W., H. Chen, J. M. Burke \& E. E. Prepas, 2005. Hepatotoxic cyanobacteria: a review of the biological importance of microcystins in freshwater environments. Journal of Toxicology and Environmental Health. Part B 8(1): $1-37$. 